\title{
Politik Kutuplaşma ve Kamu Sektörü İstihdamı
}

\section{Political Polarization and Public Sector Employment}

\author{
Prof. Dr. Sacit Hadi AKDEDE (iD) 1, Dr. Öğr. Üyesi Nazlı KEYİFLİ iD 2
}

\section{Öz}

Devletler ekonomik ve sosyal faaliyetlerini yerine getirebilmek için personele ihtiyaç duymaktadırlar. Böylelikle devletin istihdam kanalıyla ekonomiyi etkilediği görülmektedir. Literatürde kamu sektörü istihdamı üzerine çok sayıda çalışma mevcuttur. Ancak, bildiğimiz kadarıyla önceki çalışmalar kamu sektörü üzerinde politik kutuplaşmanın etkisini ele almamıştır. Bu çalışma kamu sektörü istihdamı ile politik kutuplaşma arasındaki ilişkiyi ampirik olarak araştırmaktadır. Çalışmanın kapsamına gelişmiş ve gelișmekte olan 22 ülke dâhildir ve çalışmada 2000-2018 dönemi için ilgili değişkenlerin yıllık verilerinin ortalaması kullanılmıştır. İstatistiksel analiz olarak yatay kesit analizi yapılmıştır. Politik kutuplaşma değişkeni Dünya Değerler Anketi (WVS) veri tabanından elde edilmiştir. Ekonometrik analiz sonucu elde edilen bulgular, politik kutuplaşmanın yüksek olduğu ülkelerde kamu sektörü istihdam düzeyinin oransal olarak daha yüksek olduğunu göstermektedir. Ek olarak, ampirik sonuçlarımıza göre dinsel çeşitliliğin yüksek olduğu toplumlarda kamu sektörü istihdamı da oransal olarak daha yüksektir. Çalışma bu bulguların bağlantılarını açıklamaktadır.

Anahtar Kelimeler: Kamu sektörü istihdamı, politik kutuplaşma, yatay kesit analizi

Makale Türü: Araştırma

\begin{abstract}
Governments need personnel to fulfill their economic and social activities. Thus, it is seen that the government affects the economy through the employment channel. There are many studies in the literature on public sector employment. However, as far as we know, previous studies have not addressed the impact of political polarization on the public sector. This study empirically explores the relationship between public sector employment and political polarization. 22 developed and developing are included in the scope of the study and annual data for the period 2000-2018 were used. Cross-section analysis method was used as statistical analysis. The political polarization variable was obtained from the World Values Survey (WVS) database. The findings obtained from the econometric analysis show that the increase in political polarization has a positive effect on the public sector employment level. In addition, our empirical results indicate that public employment is high in societies with high religious fractionalization. The paper explains the links between variables for these findings.
\end{abstract}

Keywords: Public sector employment, political polarization, cross-section analysis

Paper Type: Research

\footnotetext{
1'̇zmir Bakırçay Üniversitesi, İ̈BF, sacithadi.akdede@bakircay.edu.tr.

${ }^{2}$ Gümüşhane Üniversitesi, İ̈BF, n.keyifli@hotmail.com.
} 


\section{Giriş}

Ülkeler, milli gelirin önemli bir kısmını kamu hizmetlerini yerine getirmek amacıyla kullanmaktadır. Milli ekonomi içinde kamu sektörünün büyüklügünün ne olduğu ve nasıl ölçüldüğüne ilişkin çeşitli oranlar geliştirilmiştir. Kamu sektörünün milli gelir içindeki iktisadi büyüklüğünü ölçmek için genellikle kamu harcamaları, vergiler ve kamu sektörü istihdamı göstergelerinden yararlanılmaktadır. Bunlar kamu harcamalarının ve vergilerin milli gelir ya da bütçe içindeki oranları ve kamu sektörü istihdamının toplam istihdam içindeki payı şeklinde kullanılmaktadır. Şüphesiz, devlet üstlenmiş olduğu faaliyetleri yerine getirebilmek amaciyla kamu kaynaklarını kullanmakta ve bu kaynakları finanse etmek amaciyla kamu gelirlerine başvurmaktadır. Yani, devlet ekonomik ve sosyal hayatı gelir toplayıp harcama yaparak etkilemektedir. Öte yandan, ekonomik ve sosyal hayatta devletin faaliyetleri nitel ve nicel anlamda genişledikçe bu faaliyetleri yerine getirecek personele ihtiyaç duyacaktır. Dolayısıyla devletin harcama, gelir ve istihdam gibi mekanizmaları kullanarak ekonomiyi etkilediği görülmektedir.

$\mathrm{Bu}$ çalışmada kamu sektörü istihdamını etkileyen faktörler arasında politik kutuplaşmanın önemi vurgulanmaktadır. Çalışmanın çıkış noktasında kamu sektörü istihdamı ile devletin ekonomideki rolü hakkında politik kutuplaşma arasında doğrudan ilişki kuran bildiğimiz kadarıyla bir çalışma olmaması etkili olmuştur. Sosyal çeşitliliğin etkisi daha önce araştırılmış iken politik kutuplaşmanın araştırılmamış olması kanımızca literatürde önemli bir kanalın unutulmuş olmasını akla getirmektedir. Ayrıca, bildiğimiz kadarıyla Türkçe literatürde politik kutuplaşmayı Dünya Değerler Anketi verileri yardımıyla ölçen bir çalışma olmaması nedeniyle de literatürdeki var olan boşluğun doldurulması amaçlanmıştır. Bu doğrultuda ilk olarak kamu sektörü istihdamının kavramsal çerçevesi ve kamu sektörü istihdamına yönelik literatür ele alınmakta, ardından çalışmanın veri seti, yöntemi ve model tanımlanmakta olup elde edilen analiz bulgularına yer verilmektedir. Son olarak ise, bulgulardan hareketle çalışmadan elde edilebilecek çıkarımlar ile çalışma son bulmaktadır.

\section{Kamu İstihdamı: Kavramsal Çerçeve ve Literatür İncelemesi}

\subsection{Kamu İstihdamı Tanımı ve Ölçülmesi}

Devlet faaliyetlerinin modern ekonomide önemli bir rol oynadığg şüphe götürmez bir gerçektir. Devlet, çeşitli maliye ve para politikaları araçlarını kullanarak ekonomiyi etkilemektedir. Ayrıca, devletlerin ekonomik faaliyetlerinin önemli bir yönü de onların aynı zamanda bir işveren olmalarıdır. Bu çerçevede, pek çok ekonomide kamu sektörü istihdamı maliye politikasının araçları arasında yer almış ve son yirmi yılda büyük ilgi görmüştür (Gregory ve Borland, 1999, s. 3581; Vazquez ve Yao, 2009, s.541).

Kamu sektörü istihdamı, hem kamu harcamalarının önemli bir bölümünü oluşturmakta hem de çoğu ülkede toplam istihdamın önemli bir bölümünü temsil etmektedir. Bu nedenlerle, dünya genelinde kamu sektöründeki istihdamın büyümesi devletin ekonomik yapı içindeki faaliyetlerinin genişlemesi anlamına gelmiştir (Gimpelson ve Treisman, 2002, s.45). Ancak, kamu istihdam seviyelerinde ülkeler arasında büyük farklılıklar ortaya çıkmış ve aynı ülke içindeki bölgeler arasında da farklılıklar gösterebilmiştir (Katsimi, 1998, s.117).

Genel olarak, devletin görevleri arasında kamu malı/hizmeti sağlamak bireyler ve bölgeler arasında geliri yeniden dağıtmak önemli bir yer tutmaktadır. Bu iki işlev çoğu kez birbiriyle örtüşmektedir. Ekonomide kamu hizmetlerinin sayısı arttıkça devletin sosyal ve ekonomik yapı içindeki ağırlığı artmış ve bu durum kamu hizmetlerini ifa edecek personele olan ihtiyacı fazlalaştırmıştır (Alesina, vd., 2001, s.447). Ayrıca, devlet, işgücü piyasasındaki aksaklıkları düzeltmek ya da işsizliğin yüksek olduğu bölgeleri desteklemek amacıyla da personel istihdam edebilmektedir (Navruz, 2007,s. 6). Bu bağlamda, kamu sektörü istihdam düzeyinin kamu ekonomisinin büyüklüğünü belirleyen unsurlar arasında yer aldığı ifade edilebilmektedir. 
Şüphesiz, kamu hizmetlerini ifa etmek amaciyla devlet tarafından istihdam edilen personelin tümü kamu sektörü istihdamı olarak adlandırılmaktadır. 1980 yılından günümüze istihdam ve işsizlik kalıplarında kayda değer değişiklikler görülmüş ve bu durum kamu çalışanlarının sayısında belirgin artışların yaşanmasına neden olmuştur. Kamu istihdamının sayisal büyüklüğünde bilhassa büyümekte olan ekonomilerdeki eğitim, sağlık, parklar, sosyal hizmetler gibi kamu hizmetlerinin üretimine ilişkin talebin artması (Ho ve Hoon, 1998, s.73), durgunluk dönemi ve sonrasında devletin ilave iş olanaklarıyla istihdamı genişletmesi belirleyici olmuştur. Kısacası, ekonomik sistem, konjonktürel etkiler, sosyal ve siyasal yapı ve ekonomik gelişmişlik düzeyi gibi faktörler bir ülkedeki kamu sektörü istihdamının sayısal büyüklügü üzerinde etkili olabilmektedir.

Kamu hizmetlerinin alanı genişledikçe devletin hem ekonomideki ağırlığı artacak hem de devlet kamu hizmetlerini yerine getirecek personele ihtiyaç duyacaktır. Dolayısıyla, kamu kesiminin büyüklügü ve rolü kamu istihdam düzeyiyle yakından ilişkilidir. Ancak, zaman geçtikçe devletler tarafindan kamu istihdamı kamu mal ve hizmetlerinin etkin ve verimli bir şekilde sağlanmasıyla pek ilgili olmayan sebeplerle kullanılmaya başlanmıştır. Örneğin, birçok devlet, kamu istihdamını belirli gruplar lehine yeniden dağıtım aracı olarak kullanmakta olup sosyal çeşitliliğin yüksek olduğu bölgelerde işsizliği azaltmak veya sosyal yardım gibi amaçlar için kullanmaktadır (Alesina vd.,1999, s.1246). Ayrıca, Rodrik (1997), kamu istihdamını nüfusu özel sektör işsizliğine karşı korumak amacıyla da kullanılabileceğini ön görmektedir.

Öte yandan, bugün gelinen noktada, az gelişmiş ve gelişmekte olan ülkelerde aşırı personelin bulunduğu kamu işletmelerinin varlığ önemli bir sorun olarak görülmektedir (Rama, 1997, s.5). Aşırı personel alımı, aşırı sayıda kurum ve bakanlık, işlevlerin tekrarı ve hayalet işçilerin varlığı gibi durumlar verimsiz harcamalara örnek teşkil etmektedir Neticede, kamu istihdamın azaltılması söz konusu ülkelerde önemli bir ekonomik reform konusunu oluşturmaktadır (Vazquez ve Yao,2009, s.560).

Özelikle son zamanlarda ekonomi ve siyaset bilimleri alanlarında yapılan çok sayıdaki çalışmalarda kamu istihdamını belirlemede ekonomik ve sosyal tercihler kadar politik tercihlerin de bilhassa politik kutuplaşmanın etkili olduğu ortaya konulmuştur. Politik kutuplaşma, hükümetlerin politik karar alma süreçlerini etkileyebilmesinden ötürü önemli siyasi sonuçlar ortaya çıarmaktadır (Lindqvist ve Östling, 2010, s.543). Bir ülkede sosyo-ekonomik kutuplaşmanın varlığı seçmenler arasındaki bölünmeyi arttırıp politik kutuplaşmaya yol açarak devletin kamu politikaları üzerinde etkili olacağı varsayılmaktadır (Gersbach, vd.,2019, s.2).

Ekonomi literatüründe politik kutuplaşmanın genel kabul görmüş ve standartlaşmış bir tanımı bulunmamaktadır (Akdede, 2012, s.20). Politik kutuplaşmanın genel itibariyle toplumsal huzursuzluğun varlığı ve siyasi ve sosyal alanda yaşanan çekişmelerle ilişkili olduğu ifade edilmektedir (Estaban ve Ray, 2011, s.1345). Şüphesiz, toplumda kutuplaşmanın ortaya çıkmasında sosyokültürel özelliklerdeki farklılıklar, dünya görüşündeki ve ahlak anlayışındaki farklılıklar, ideolojik farklılıklar ve yaşam çevresindeki farklılıklar etkili olabilmektedir (Fiorina ve Abrams, 2008, s.567).

Genel olarak, kutuplaşma olgusu toplumdaki bireylerin toplumsal bazı özelliklere göre kümeler halinde gruplanmasıdır. Kutuplaşmanın söz konusu olduğu toplumda en az iki küme bulunmaktadır. Toplumdaki bireyleri belli kümeler halinde gruplandıran özellikler, eşitsizlik, gelir ve siyasi ideoloji farklılıkları olabilmektedir. Ancak, bu gruplanmalarda grubun kendi içinde yüksek seviyede homojenliğe sahip olması ve gruplar arasında ise yüksek seviyede heterojenlik bulunması gerekir (Esteban ve Ray, 1994, s. 819-824). Yani, kutuplaşma grupların veya kümelenmelerin oluşumu olarak ifade edilebilir (Akdede, 2012, s. 21).

Genel kabul gören tanımıyla kamu istihdamı, kamu hizmetlerinin görülmesi amacıyla devlet ve kamu sektörü tarafından istihdam edilen personelin tümü olarak değerlendirilmektedir (Hammouya,1999, s.7) Ancak, kamu istihdamı tanımlanırken bazı problemler bulunmaktadır. Örneğin, bazı ülkelerde öğretmen ve sağlık çalışanları kamu sektörü istihdamı içinde yer alırken 
diğer ülkelerde yer almamaktadır. Bazı ülkelerde ise milis güçler kamu sektörü istihdamına dâhil edilirken diğer ülkelerde askeri personel olarak kabul edilmektedir. Öte yandan, ülkelerin kamu sektörü istihdamını nasıl tanımladıkları her zaman açık olmayabilmektedir. Bu durum ülkeler arasında kamu sektörü istihdamının karşılaştırılmasında zorluklar ortaya çıkarmaktadır (SchiavoCampo vd., 1997, s.4).

$\mathrm{Bu}$ bağlamda, literatürde birkaç kamu istihdamı veri seti yer almaktadır. Bu çalışmada, daha fazla dönemi kapsaması ve daha az eksik veri olmasından dolayı Uluslararası Çalışma Örgütü (ILO)'nun Kamu Sektörü Veri Seti kullanılmıştır. ILO genel devlet çalışanlarını, tüm devlet birimlerini ${ }^{3}$, sosyal güvenlik kurumların $1^{4}$ ve kamu otoritesi tarafından kontrol ve finanse edilen kâr diğer amacı gütmeyen kuruluşlarda ${ }^{5}$ çalışanlar olarak tanımlar. Kısacası, kamu istihdamı, merkezi hükümette, yerel yönetimlerde ve mali olmayan kamu sektöründe çalışanlardan oluşmaktadır. ILO'ya göre kamu sektörü çalışanlarının bileşenleri Şekil 1'de sunulmuştur.

Şekil 1. Kamu sektörü istihdamı bileşenleri

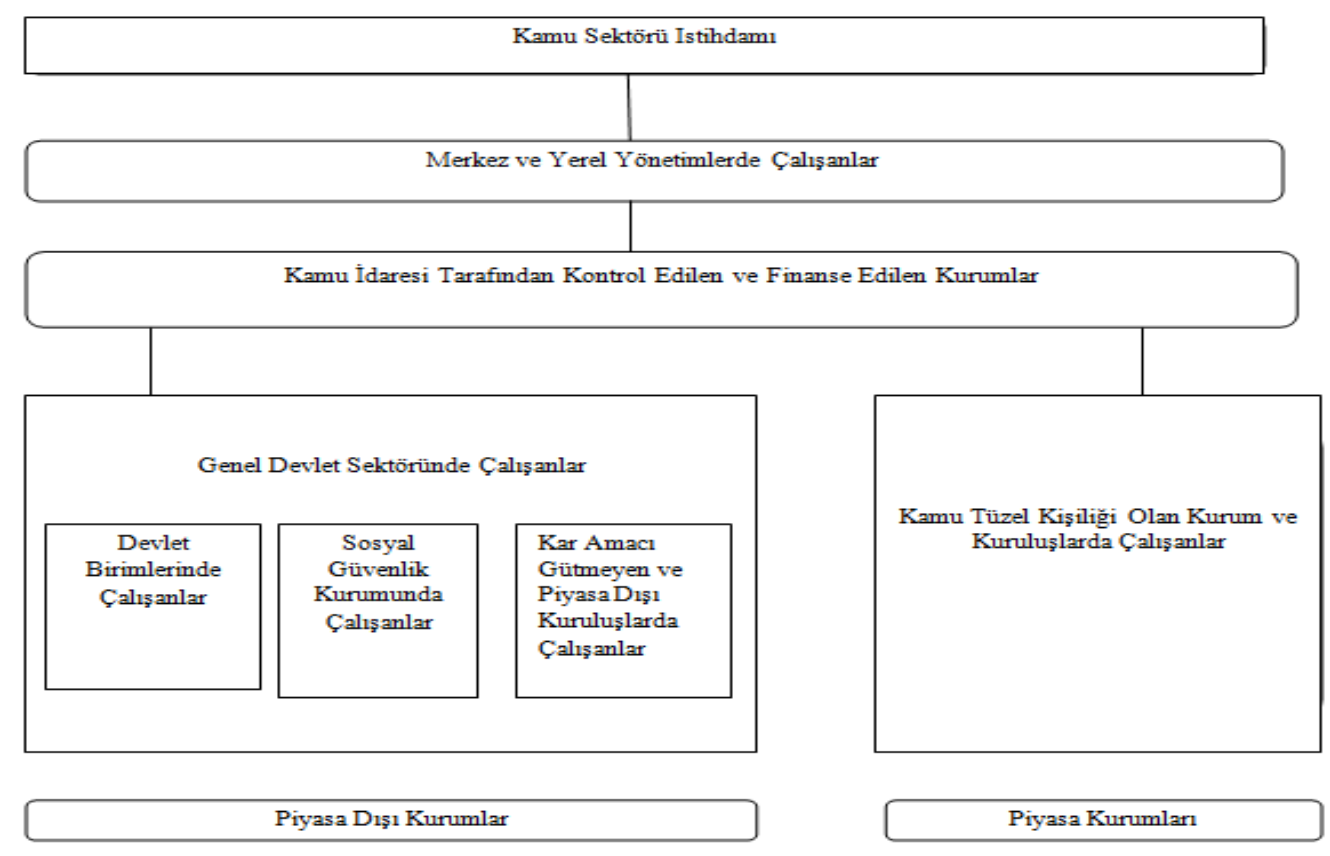

Kaynak: Hammouya (1999)

\subsection{Kamu İstihdamının Gelişimi}

$\mathrm{Bu}$ çalışmada kamu sektörü istihdamı ve politik kutuplaşma arasındaki ilişki ele alınmıştır. Bu doğrultuda Grafik 1'de çalışmada ele alınan 22 ülkenin 2000-2018 dönemine ilişkin ortalama kamu sektörü istihdamının seyri gösterilmektedir. Yıllar itibariyle tüm ülkelerde kamu sektörü istihdamının artış seyrin varlığı dikkat çekmektedir. İlgili tabloda görüldüğü üzere, kamu sektörü istihdamında 2000 yılından 2013 y1lına kadar gözle görülür bir artış yaşanırken 2013 yılından 2017 yılına kadara kamu istihdamında kademeli olarak azalış olduğu 2018 yılında ise yükselişe geçtiği görülmektedir. Söz konusu ülkelerde ortalama kamu istihdamı 2000 yılında 1130.171 bin kişi iken 2013 y1lında 2769.083 bin kişi 2018 yılında ise keskin bir yükseliş olup

\footnotetext{
${ }^{3}$ Devlet birimleri, devletin görevlerini yerine getirir ve herhangi bir düzeydeki hükümetin (merkezi, eyalet veya il, yerel) savunma, kamu düzeni, sağlık, eğitim, kültürel ve diğer sosyal hizmetlerin yürütülmesi ile uğraşan tüm kurum, birim ve kuruluşlarıdır.

${ }^{4}$ Sosyal güvenlik fonları, toplumu bir bütün olarak ya da geniş bir kesim olarak kapsayan sosyal sigorta planlarıdır ve bunlar, hükümet tarafindan empoze, kontrol ve finanse edilir.

${ }^{5}$ Kâr amacı gütmeyen kuruluşlar, devlet birimlerinden özerk olan tüzel kişilerdir. Kamu otoritesi tarafindan finanse ve kontrol edildiği gibi piyasa dışında değildir ve genel hükümet altında sınıflandırılırlar.
} 
997.109 bin kişi olduğu gözlemlenmektedir. Bu durum 1990'larda küreselleşme ve teknolojik gelişmeye bağlı olarak artan işsizliğin devlet güvencesinde istihdam edilmesine bağlanmaktadır. Ayrıca yaşanan küresel krizler sonrasında istihdamdaki toparlanmaya binaen işsizlerini özel kesimde de istihdam edilmesiyle, kamu istihdamı 2013 yılından sonra düşmeye başlamıştır. İstihdamdaki bu düşüş özelleştirme ve verimlilik hipotezi ${ }^{6}$ gibi iki farklı süreci yansıtıyor olabilmektedir.

Grafik 1. Kamu istihdamının seyri (bin) (2000-2018)

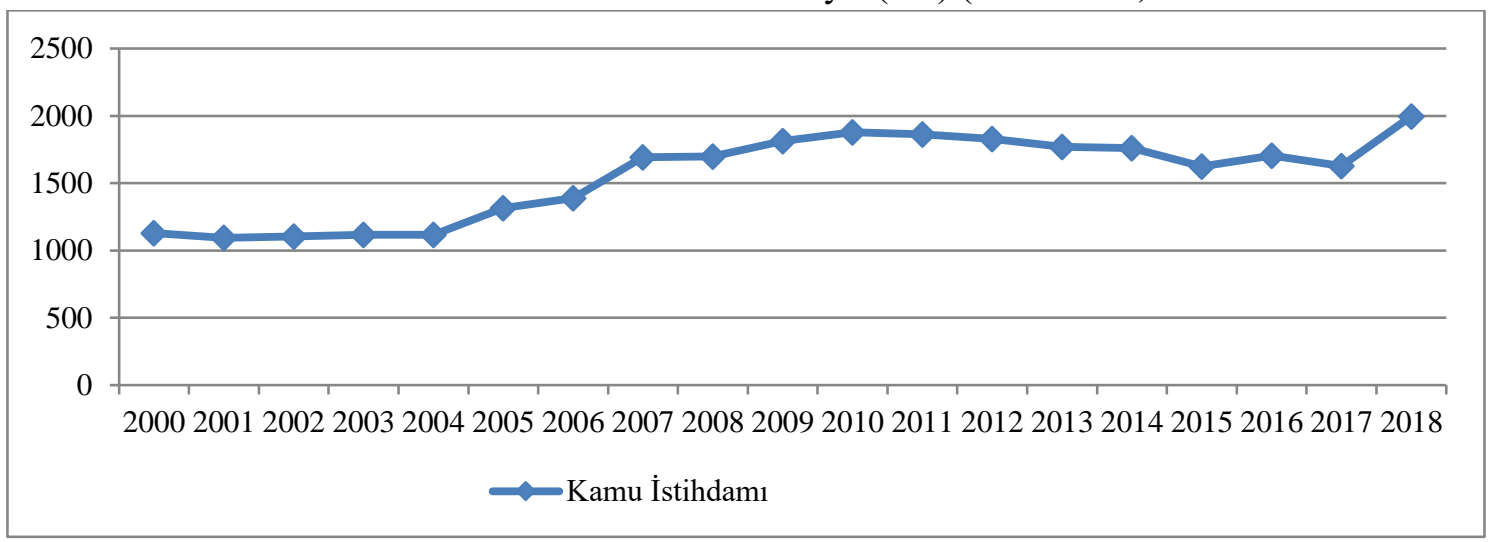

Kaynak: Uluslararası Çalışma Örgütü (ILO)'nun 2000-2018 dönemine ilişkin verileriyle derlenmiştir.

Türkiye'de 2000-2017 y1lına ilişkin kamu istihdam değişimi Grafik 2'de gösterilmektedir. Grafikte görüldüğü üzere ilgili dönemde kamu sektörü istihdamının Türkiye'de dalgalı bir seyir izlediği görülmektedir. 2000 yılında 3109 bin kişi iken 2004 yılını kadar artış gösterip 2004 yılında azalıp 2960 bin kişi kamuda istihdam edilmiştir. 2004 yılından sonra kamu sektörü istihdamı artış eğilimi gösterse de 2007 yılında 2645 bin kişiye gerilemiştir. 2007 yılından sonrada artış eğilimine girdiği gözlenmektedir. Ayrıca, Türkiye'de 2014 yılından sonra ekonomik büyüme ve istihdam teşvik politikalarında yaşanan gelişmeler çerçevesinde kamu sektörü istihdamının 2016 ve 2017 yıllarında sırasıyla 3041 bin ve 3026 bin kişi olduğu görülmektedir.

Grafik 2. Türkiye'de kamu istihdamındaki değişim (bin) (2000-2017)

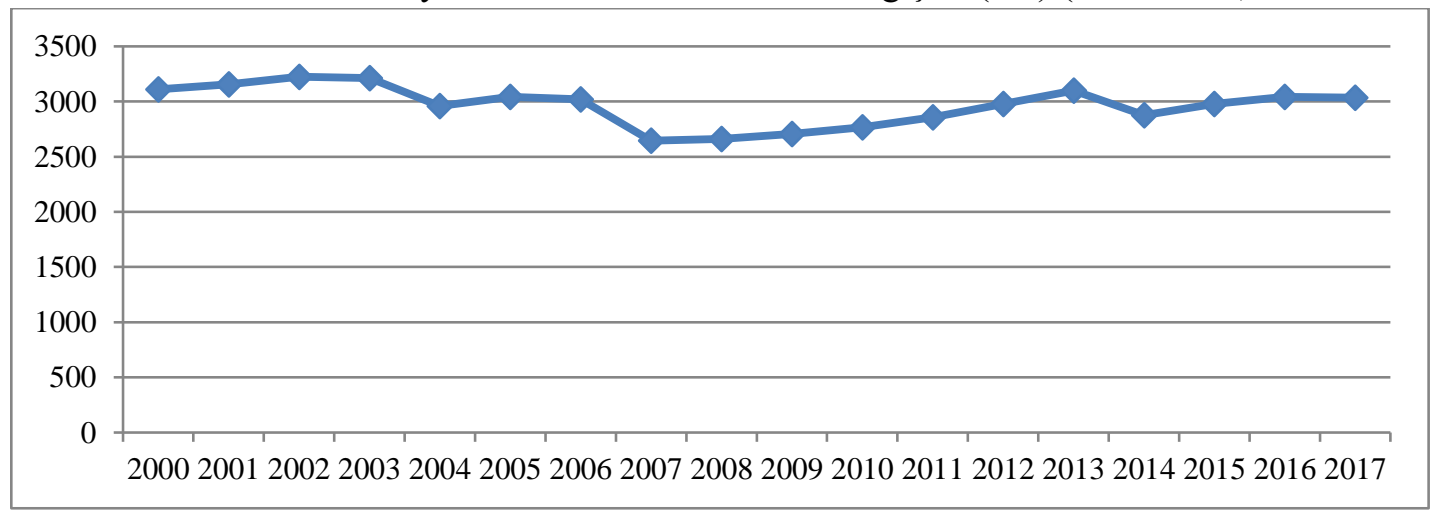

Kaynak: Uluslararası Çalışma Örgütü (ILO)'nun 2000-2018 dönemine ilişkin verileriyle derlenmiştir.

\footnotetext{
6 Verimlilik hipotezine göre devletlerin diğer ülkelerle rekabet edebilmesi için daha küçük kamu sektörüne sahip olması gerekmektedir. Özel sektör kamu sektöründen daha verimlidir ve ekonomide kamu sektör işlerinin artması özel sektör işlerinin dışlanmasına neden olabilmektedir. Bu çerçevede yüksek bir ticaret düzeyi yani ekonomik küreselleşme ülkeler arasında rekabeti arttıracak (verimliliği arttıracak) ve bu durumda devletlerin refah devletini finanse etme kapasitesini azalmaktadır (Rodrik, 1998).
} 
Grafik 3'te ilgili ülkelerde 2000-2018 dönemine ilişkin ortalama değerler olarak toplam nüfus ve işgücü içindeki kamu istihdamının payları gösterilmektedir. Grafik değerlendirildiğinde, söz konusu ülkelerin genelinde beklendiği gibi toplam işgücü içindeki kamu istihdamının payının toplam nüfus içindeki kamu istihdamının payına göre daha yüksek olduğu görülmektedir. En yüksek toplam işgücü içinde kamu istihdamına sahip ülkeler sırasıyla, Finlandiya (\%23.82), Fransa (\%21.78), Letonya (\%20,57), Estonya (\%19.86) ve Litvanya (\%19,87)'dır. İşgücü içinde kamu istihdamı payı en düşük Sirbistan $(\% 4,90)$, Arnavutluk $(\% 8,58)$ ve Polonya $(\% 9,57)$ gibi ülkelerde görülmektedir. En yüksek toplam nüfus içinde kamu istihdamı ise Romanya $(\% 14,29)$ ve Finlandiya $(\% 11,53)$ gibi ülkelerdedir. Nüfus içinde kamu istihdamının payının en düşük olduğu ülkeler ise sirasıyla, Yunanistan $(\% 3,10)$, Hirvatistan $(\% 3,12)$, Arnavutluk $(\% 3,93)$ ve Türkiye $(\% 3,99)$ 'dir.

Grafik 3. Kamu istihdamının nüfus ve işgücüne oranı (\%) (2000-2018 ortalamaları)

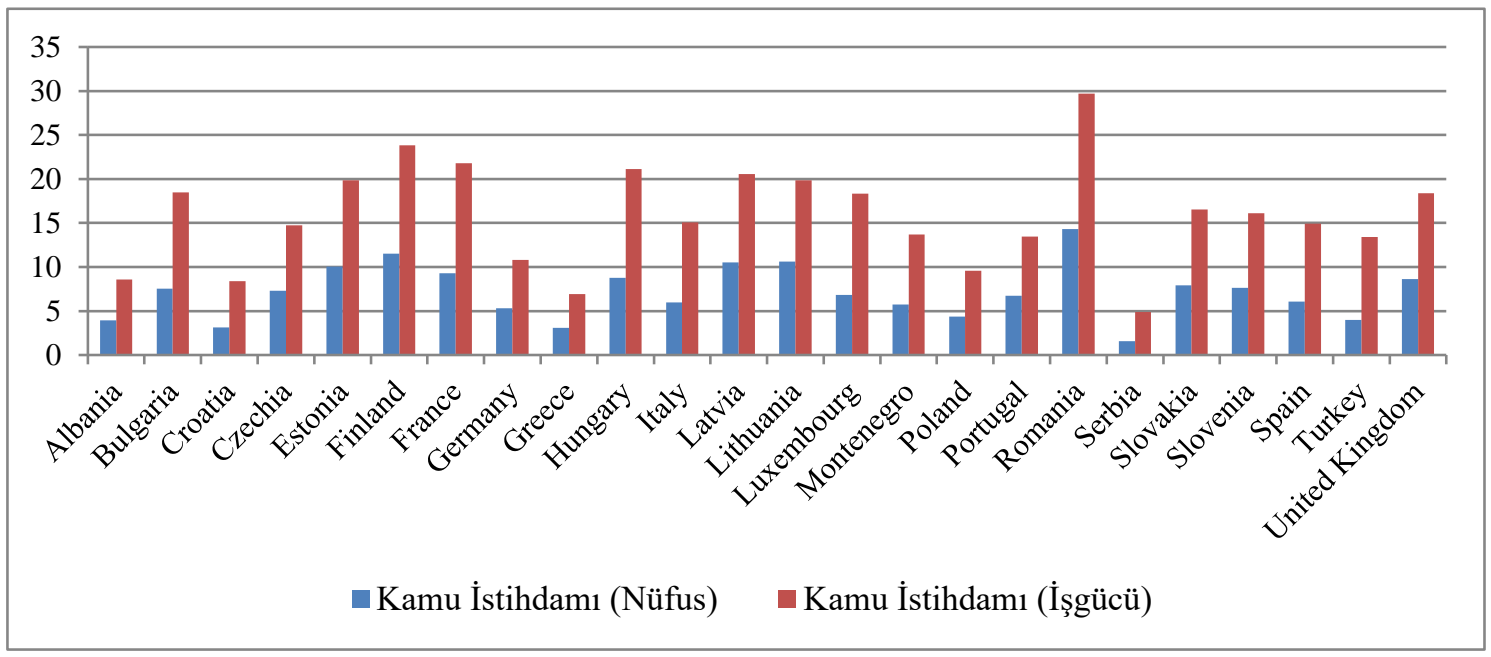

Kaynak: Uluslararası Çalışma Örgütü (ILO) 2000-2018 dönemine ilişkin verileriyle derlenmiştir.

\subsection{Literatür İncelemesi}

Literatürde devletin işveren rolünü ele alan çalışmaların görece az olduğu görülmektedir. Bu çalışmaların bazıları vaka incelemesi gibi belirli bir ülkeye yoğunlaşırken diğerleri ise ülke grubu çalışmalarıdır. Bunlardan bazıları; Cusack vd. (1989), 1963-1983 dönemi için 17 OECD ülkesinin verisini kullanarak yapmış oldukları ampirik çalışmada sol partilerin kamu istihdamını genişletme eğiliminde olduğu sonucuna ulaşmışlardır. Benzer şekilde, Murrell (1985) ise 19 OECD ülkesi için yapmış olduğu araştırmasında hükümetin sosyalist politikalara ilişkin uygulamalarında ortaya çıkan 100 puanlık bir artışın kamu istihdamında 25 puanlık bir artışa neden olduğu sonucunu elde etmiştir. Tait ve Heller (1984), kamu istihdamının boyutunu açıklayan ortak faktörlerin olup olmadığını araştırmak için 1980 yılına ait 61 ülkenin verilerini kullanarak yaptıkları ampirik çalışma sonucunda kişi başına düşen gelir arttıkça kamu istihdamının da arttı̆̆ını belirlemişlerdir.

Blais vd. (1993) 1960-1987 dönemi için 15 liberal demokrasi ülkesi üzerine yaptıkları panel veri çalışmalarında hükümet ideolojisinin kamu istihdamı üzerindeki etkisini araştırmışlardır. Analiz sonucunda sol partilerin sağ partilere göre daha fazla kamuda istihdam oluşturdukları tespit edilmiştir.

Rama (1997) tarafından yapılan çalışmada 1970'ler, 1980'ler ve 1990'lar dönemleri için 90 ülkenin verisi kullanılarak kamu sektörü istihdamının belirleyicileri araştırılmıştır. Panel veri 
analizi yönteminin sonuçlarına göre söz konusu ülkelerde kişi başı GSYİH ile birlikte kamu istihdamının da arttığı tespit edilmişsir.

Katsimi (1998) 1961-1987 dönemini kapsayan çalışmasında 19 OECD ülkesine ilişkin kamu sektörü büyüklüğü için sosyal sigorta hipotezini test etmiştir. En küçük kareler yöntemine göre kamu sektöründeki genişlemenin kamu istihdamı üzerinde olumlu etkisi olduğu sonucuna ulaşılmıştır. Kısacası, kamu istihdamı olumsuz ekonomik koşullara karşı bir tür sigorta ve özel sektör işsizliğine karşı "tamponlamanın” bir yolu olarak görülmektedir.

Alesina vd. (2000) 1990 döneminde ABD Eyaletlerinin verilerini kullanarak gelir eşitsizliği ve kamu istihdamı arasındaki ilişkiyi yatay kesit yöntemi ile araştırmışladır. Analiz sonucunda, ABD'nin gelir eşitsizliği ve etnik parçalanmanın yüksek olduğu eyaletlerde kamu istihdamının yükssek olduğu sonucuna ulaşmışlardır.

Huber ve Stephens (2000) 1962-1987 dönemini kapsayan çalışmalarında 16 OECD ülkesine ilişkin sosyal devlet anlayışının mal ve hizmetlerin sunumundaki artışın ve uluslararası farklılaşmanın nedenleri en küçük kareler (EKK) ve genelleştirilmiş en küçük kareler yöntemleri kullanılarak araştırılmıştır. Çalışmanın sonucuna göre kadınların işgücüne katılımlarının toplumsal hizmetlerin devlet tarafindan sunumunu güçlendirdiği sonucuna ulaş1lmıştır.

Gimpelson vd. (2000) tarafından yapılan çalışmada 1992-1998 döneminde Rusya’yı 78 bölgeye ayırarak gelir eşitsizliği ile kamu istihdamı arasındaki ilişki en küçük kareler ve genelleştirilmiş en küçük kareler yöntemlerini kullanarak araştırmıştır. Çalışmanın sonucunda eşitsizliğin, işsizlik oranının ve sosyal çeşitliliğin yüksek olduğu bölgelerde kamu istihdamının arttığı tespit edilmiştir.

Alesina vd. (2001) çalışmasının amacı 1995 döneminde İtalya için gelir eşitsizliği ile kamu istihdamı arasındaki ilişkiyi araştırmaya yöneliktir. Çalışmanın ampirik analizinde yatay kesit yöntemi kullanılmıştır. Analiz sonucuna göre İtalya'da kamu istihdamının yeniden dağıtım aracı olarak kullanılabileceği tespit edilmiştir.

Sevillano ve Villallonga (2004), 1990-1999 yılları arasında İspanya'daki bölgesel kamu istihdamı dağılımının belirleyicilerinin incelendiği çalışmalarında kişi başı GSYİH'nin düşük olduğunu ve sol ideolojiye sahip partiler ile yönetilen bölgelerde kamu istihdamının arttığını tespit etmişlerdir.

Vazquez ve Yao (2009) tarafindan yapılan çalışmada gelişmiş ve gelişmekte olan 74 ülkedeki kamu sektörü istihdamı ile adem-i merkeziyetçilik arasındaki ilişki araştırılmıştır. 19852005 dönemini kapsayan ampirik çalışmada iki aşamalı en küçük kareler yöntemi ve genelleştirilmiş momentler metodu (GMM) kullanılmıştır. Analiz sonucuna göre, Adem-i merkeziyetçilik derecesi arttıkça kamu istihdamının arttığı sonucuna ulaşılmıştır. Ayrıca çalışmada kamu istihdamının üniter yapılı ülkelerde daha yüksek olduğu tespit edilmiştir.

Mattos ve França (2011) 1991-2004 dönemi için Brezilya belediyelerinin verilerinden yararlanarak kamu istihdamı ile gelir dağılımı arasındaki ilişkiyi açıklamaya çalışmışlardır. Kamu istihdamının yeniden dağıtım mekanizması olarak kullanılabileceği sonucuna ulaşılmıştır.

Gözgör vd. (2019) tarafindan yapılan çalışmada 2000-2016 döneminde gelişmekte olan 92 ülkede tazminat ve verimlilik hipotezleri panel veri yardımıyla araştırılmıştır. Çalışmanın sonucunda, küresel rekabetin kamu istihdamını azalttığı tespit edilmiştir. Ayrıca, söz konusu ülkelerde verimlilik hipotezinin geçerli olduğu görülmüştür.

\section{Veri Seti}

Çalışmada kamu istihdamı ile politik kutuplaşma arasındaki ilişki ampirik olarak incelenmektedir. Bu çerçevede, Uluslararası Çalışma Örgütü (ILO) veri tabanında bulunan 
gelişmiş ve gelişmekte olan $22^{7}$ ülkenin 2000-2018 dönemine ait yıllık ortalama veriler kullanılarak kamu istihdamı ve politik kutuplaşma arasındaki ilişki yatay kesit analizi yöntemiyle araştırılmıştır. Çalışmada belirtilen dönem ve ülkeler, verilerin elde edilebilirliğine göre seçilmiştir. Modelde kullanılan değişkenlere ilişkin bilgiler Tablo 1'de gösterilmektedir.

Tablo 1. Çalışmanın veri seti

\begin{tabular}{|c|c|c|c|}
\hline Değişken Türü & Değişkenin Adı & Kisaltması & Kaynağı \\
\hline Bağımlı Değişken & Kamu İstihdamı & İstihdam & Uluslararası Çalışma Örgütü (ILO) \\
\hline \multirow{6}{*}{$\begin{array}{l}\text { Bağımsız } \\
\text { Değişkenler }\end{array}$} & Politik Kutuplaşma & PK & $\begin{array}{l}\text { Dünya Değerler Anketi (World Values } \\
\text { Survey) }\end{array}$ \\
\hline & Kişi başı GSYİH & $\mathrm{G}$ & \multirow[b]{3}{*}{ Dünya Bankası (WB) } \\
\hline & İşsizlik Oranı & $\dot{\mathrm{I} O}$ & \\
\hline & Nüfus Yoğunluğu & NY & \\
\hline & $\begin{array}{l}\text { Dini Çeşitlilik (Religious } \\
\text { Fractionalization) }\end{array}$ & DIN & The Quality of Government Dataset \\
\hline & Küreselleşme & $\mathrm{KOF}$ & KOF Index \\
\hline
\end{tabular}

Kamu İstihdamı: bağımlı değişken kamu istihdamıdır. Söz konusu değişken Uluslararası Çalışma Örgütü'nün Kamu Sektörü veri setinden temin edilmiş olup ham verilerin toplam nüfus ve toplam işgücü içindeki payları tarafımızca hesaplanarak modelde iki bağımlı değişken olarak dâhil edilmiştir. Bu iki oranı daha önce Tait ve Heller (1983)'de kamu istihdam göstergeleri olarak kullanmıştır. ILO veri setindeki kamu çalışanları genel devlet yönetim ve kamu kurumları çalışanlarından oluşmaktadır.

Modelde kullanılan bağımsız değişkenlere bakıldığında;

Politik Kutuplaşma (Political Polarization): çalışmada politik kutuplaşma değişkeni için Lindqvist ve Östling (2010) ve Grechyna (2016) çalışmalarında kullandıkları Dünya Değerler Anketi (World Values Survey) veri tabanında bulunan "government responsibility" anket sorusuna verilen yanıtların standart sapmasıyla hesaplanan ölçüm değeridir. Bu ölçüm değeri vatandaşların kendi bildirimleriyle ortaya çıkan politik tercihlere dayanan bir politik kutuplaşma ölçüsüdür. Yani, bu değer seçmenlerin kendi tercihleri doğrultusunda bildirdiği siyasi tercihlere dayanır. Dünya Değerler Anketi veri tabanında bulunan anket soruları her ülkede yaklaşık 1.000 kişiyle yüz yüze görüşmeye dayanarak elde edilen cevaplardan oluşmaktadır. Çalışmada kullanılan "government responsibility" anket sorusu şöyledir: devlet insan hayatında daha çok sorumluluk almalıdır (1); bireyler kendileri daha çok sorumluluk almalıdır (10). 1'den 10'a doğru giden bir ölçeklendirmede, bireylerin 1 ile 10 arasında bir değer seçmesi istenmektedir. Her ülkede bireylerin bu sorulara verdikleri yanıtlardan oluşan bir ortalama değeri ve bir de standart sapma değeri vardır. Ortalama değerler genellikle 5 civarında toplandığından iyi bir gösterge olmamaktadır. Bundan dolayı literatürde standart sapma değerleri politik kutuplaşma değerleri olarak kabul edilmektedir (Lindqvist ve Östling, 2010 ve Grechyna, 2016). Politik kutuplaşma teorik olarak kamu sektörü istihdamını arttırıcı ya da azaltıcı etki yapabilir. Ampirik sonuçlar belirleyici olacaktır.

Dinsel Çeşitlilik (Religious Fractionalization): "The Quality of Government Dataset" veri tabanından elde edilmiştir. Söz konusu değişken 0 ila 1 arasında değerler alır. 0 dinsel çeşitliliğin olmadığını 1 ise dinsel çeşitliliğin yüksek olduğu anlamına gelmektedir. Toplumsal çeşitliliğin yüksek olduğu toplumlar yani heterojen toplumlar devletten daha fazla hizmet ve daha

\footnotetext{
${ }^{7}$ Almanya, Arnavutluk, Bulgaristan, Hırvatistan, Çekya, Estonya, Finlandiya, Fransa, Yunanistan, Macaristan, İtalya Letonya, Litvanya, Lüksemburg, Karadağ, Polonya, Portekiz, Romanya, Sirbistan, Slovakya, Slovenya, İspanya, Türkiye, Birleşik Krallık.
} 
fazla devlet güvencesinde çalışma arzusu içinde olabilmektedirler. Bu çerçevede heterojen toplumların kamu istihdamı üzerinde pozitif bir etkiye sahip olması beklenmektedir.

Nüfus Yoğunluğu: Dünya Bankası veri tabanından elde edilmiş ve söz konusu değiş̧ken kilometre kareye düşen insan sayısı olarak alınmıştır. Ölçek ekonomilerinin varlığı sebebiyle nüfus yoğunluğu ve devletin boyutu arasında negatif bir ilişki beklenmektedir.

Kişi başı GSYIH: Dünya Bankası veri tabanından elde edilmiş ve veri ABD doları cinsinden kullanılmıştır. Kişi başı GSYİH ile kamu istihdamı arasında ise pozitif bir ilişki beklenmektedir.

İssizlik Oranı: Dünya Bankası veri tabanından elde edilmiş ve toplam işgücünün yüzdesi olarak alınmıştır. Ülkelerin ekonomik sosyal ve siyasal yapısındaki farklılık ötürü işsizlik oranındaki artışı kamu istihdamı üzerindeki etkisi pozitif/negatif olabilmektedir.

Küreselleşme: KOF endeksi ile ölçülen genel küreselleşme değişkeni kullanılmıştır. Endeksin yapısı ekonomik, siyasal ve sosyal bileşenler olmak üzere üç ana bileşenden oluşmaktadır. Ekonomik küreselleşme, uzun vadeli sermaye mal ve hizmet akışlarına ilişkin bilgileri ifade eder. Siyasal küreselleşme, hükümet politikalarının yayılması olarak ifade edilir. Sosyal küreselleşme ise bilgilerin insanlar arasında yayılımını ifade eder. Özetle, genel küreselleşme endeksi ekonomik, siyasi ve sosyal küreselleşme endekslerinin birleştirilmesi sonucu ortaya çıkmaktadır. Genel küreselleşme endeksi 1-100 arasında değerler alır ve 1 minimum küreselleşmeyi 100 ise maksimum küreselleşmeyi ifade eder. Küreselleşmenin kamu istihdamı üzerinde negatif etkise sahip olması beklenmektedir.

\section{Yöntem ve Bulgular}

Çalışmada kullanılan ekonometrik model yardımıyla politik kutuplaşma faktörünün kamu istihdamı üzerindeki etkisi araştırılmıştır. Bu bağlamda, oluşturulacak model kapsamında, dinsel çeşitlilik, kişi başı GSYİH, işsizlik oranı, nüfus yoğunluğu, ülke yüzölçümü, küreselleşme gibi açıklayıcı değişkenler modele dahil edilmiştir. Kamu istihdamın toplam nüfusa ve işgücüne oranları modellerin bağımlı değişkenleridir. Söz konusu değişkenler gelişmiş ve gelişmekte olan 22 ülke için 2000-2018 dönemi verilerinin ortalaması kullanılarak yatay kesit analiz yöntemi ile tahmin edilmiştir.

Ekonometride verilere ilişkin veri yetersizliği, verilerin her zaman birimi için yokluğu ve yeni tutulmaya başlanması gibi nedenlerden dolayı veriler analizin niteliğini belirlemektedir. $\mathrm{Bu}$ gibi durumlarda değişkenler arasındaki ilişkinin araştırılmasında yatay kesit analiz yönteminden yararlanılmaktadır. Yatay kesit analizi, zamanın bir noktasında hane halkları, bireyler, firmalar, ülkeler ya da diğer farklı birimlerin örneklerinden oluşmaktadır (Tatoğlu, 2013, s.2). Ancak, elde edilecek tahminlerin sabit varyans, normal dağılım, içsel ve çoklu bağlantı sorunları olup olmadığı tanısal testler yardımıyla kontrol edilmesi gerekmektedir. Yatay kesit ekonometrik yönteminin kullanıldığ 1 çalışmalarda genellikle değişen varyans problemi ile karşılaşılmaktadır. $\mathrm{Bu}$ nedenle söz konusu analizlerde, tahminlerin değişen varyans probleminin giderilerek yapılması gerekmektedir (Wooldridge, 2001, s. 55). Bu çalışmada en yaygın yöntem olan white testi kullanılarak değişen varyans problemi giderilerek nihai tahmin modeline ulaşılmıştır.

Öte yandan, yatay kesit verilerinde dikkat edilmesi gereken bir diğer konu ise $R^{2}$ ile ilgilidir. Belirlilik katsayısı olarak bilinen yani modelin anlamlılık gücünü gösteren $R^{2}$, bağımlı değiş̧kendeki değişmelerin ne kadarının bağımsız değişkenlerdeki değişmeler tarafından açıklanabildiğini ifade etmektedir. Yatay kesit verileri kullanılarak yapılan tahminlerde $R^{2}$, lerin genel olarak küçük olduğu bilinmektedir. Örneğin, Wallace ve Silver (1988), $R^{2}{ }^{2}$ nin 0.3 ve daha küçük bulunmasının yatay kesit verisiyle çalışan analizlerde yaygın olarak görüldüğünü aynı şekilde Studenmund (1992), yatay kesit serilerde 0.5 büyüklüğünde $R^{2}$ 'nin iyi bir uygunluk oluşturduğunu ifade etmektedir (Ağır ve Kar, 2010, s.167). Bu bağlamda, En küçük kareler (EKK) yöntemi ile elde edilen tahmin sonuçları Tablo 5'de verilmiştir. Tahmin edilen modellere 
ait $R^{2}$ değerleri sırasıyla 0.58 ve 0.53 olarak saplanmıştır. Dolayısıyla, tahmin modellerinden elde edilen $R^{2}$ değerlerinin düşük olmadığını ve tahmin modellerin anlamlı olduğunu göstermektedir. Öte yandan, yatay-kesit analize ilişkin diagnostik testler incelendiğinde, White ve Ramsey Reset test istatistiklerinin sonuçları, kurulan modelde değişen varyans sorunu olmadığını, açıklayıcılık gücünün kabul edilebilir olduğunu ve tahmin modelinin doğru spesifikasyonda kurulduğu görülmektedir.

Kamu istihdamı ile politik kutuplaşma arasındaki ilişkiyi belirlerken Vazquez ve Yao (2009) ve Alesina vd. (2000) çalışmalarında kullandığı değişkenlerden yararlanarak çalışmanın tahmin modeli aşağıdaki şekilde tanımlanmıştır:

$$
\begin{aligned}
& \text { Ln } \dot{I} \dot{I} \text { stihd }=\beta_{0}+\beta_{1} P K+\beta_{2} L n G+\beta_{3} \dot{I O}+\beta_{4} N Y+\beta_{5} \ddot{U} Y+\beta_{6} D I N+\beta_{7} K O F+ \\
& \beta_{8} O E C D+\varepsilon
\end{aligned}
$$

Burada $\beta_{0}$ sabit terimi, $\beta_{1} \ldots \beta_{8}$ eğim parametrelerini, $\varepsilon$ ise hata terimini ifade etmektedir.

Önsel bir bilgi edinmek amacıyla öncelikle tanımlayıcı istatistiklere bakılmıştır. Modelde yer alan değişkenlere ilişkin tanımlayıcı istatistikler Tablo 2'de sunulmuştur. Analiz döneminde (2000-2018), ülkelerin nüfusun bir yüzdesi olarak kamu istihdamı ortalama yaklaşık olarak \% 7 seviyesinde iken işgücünün bir yüzdesi olarak kamu istihdamı ise yaklaşık olarak ortalama \% 16 seviyesinde olduğu görülmektedir. Kamu istihdamı nüfusun bir yüzdesi ve işgücünün bir yüzdesi olarak sırasıyla Sirbistan (\%1.59-\%4.9) oranlarıyla en düşük iken Romanya'da (\%14.29-\%29.67) oranıyla en yüksek seviyededir. Ülkelerin politik kutuplaşma değerinin ortalaması 2.62 düzeyindedir. Politik kutuplaşmanın en düşük olduğu ülke (2.15) seviyesiyle Yunanistan iken politik kutuplaşmanın en yüksek olduğu ülke (3.42) seviyesiyle Romanya'dır. Öte yandan, dini çeşitliliğin en düşük olduğu ülke Türkiye (0.004) iken en yüksek dini çeşitliliğe sahip ülke ise Birleşik Krallık (0.69)'tır. Küreselleşmenin en düşük olduğu ülke 62.30 endeks değeriyle Arnavutluk iken en yüksek küreselleşmeye sahip ülke ise 88.4 endeks değeri ile Birleşik Krallik'tır.

Tablo 2. Tanımlayıcı istatistikler

\begin{tabular}{llllll}
\hline Değişken Adı & Gözlem & Ortalama & Std. Hata & Minimum & Maksimum \\
\hline $\begin{array}{l}\text { Kamu İstihdamı (Nüfusun } \\
\text { Yüzdesi) }\end{array}$ & 24 & 7.121 & 3.037 & 1.591 & 14.296 \\
\hline $\begin{array}{l}\text { Kamu İstihdamı (İşgücünün } \\
\text { Yüzdesi) }\end{array}$ & 24 & 15.799 & 5.837 & 4.906 & 29.679 \\
\hline $\begin{array}{l}\text { Politik Kutuplaşma } \\
\text { (Endeks) }\end{array}$ & 24 & 2.62 & 0.262 & 2.15 & 3.42 \\
\hline Dinsel Çeşitlilik (Endeks) & 22 & 0.389 & 0.200 & 0.004 & 0.694 \\
\hline Küreselleşme (Endeks) & 24 & 79.238 & 6.242 & 62.304 & 88.405 \\
\hline GSYİH & 24 & 26633.69 & 22039.05 & 5079.401 & 110742.3 \\
\hline $\begin{array}{l}\text { Nüfus Yoğunluğu } \\
\text { (Nüfus/Ülke Yüzölçümü) }\end{array}$ & 24 & 107.302 & 62.765 & 17.569 & 257.884 \\
\hline \begin{tabular}{l} 
İşsizlik Oranı (\%) \\
\hline
\end{tabular} & 24 & 9.823 & 3.644 & 4.295 & 15.977 \\
\hline
\end{tabular}

Şekil 2 ve Şekil 322 ülkede değişkenler arasındaki ilişsiyi veren serpilme diyagramında politik kutuplaşma ile kamu istihdamı (sırasıyla nüfus ve işgücü içindeki yüzdeleri) arasında pozitif yönlü bir ilişkinin mevcut olduğunu göstermektedir. Yani, bu diyagramlardan anlaşılacağ 1 üzere, ele alınan ülke örnekleminde politik kutuplaşma arttıkça kamu istihdamı yüzde olarak artmaktadır. 
Şekil 2. Kamu istihdamı (nüfus)- politik kutuplaşma ilişkisi

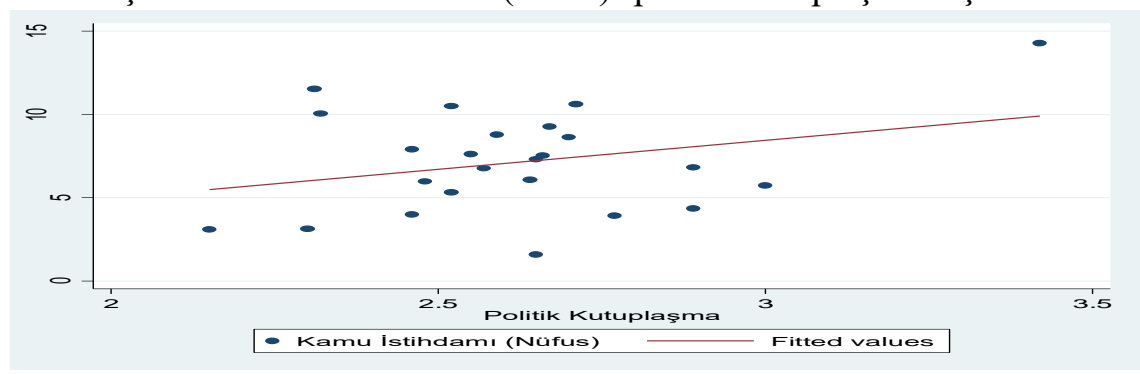

Şekil 3. Kamu istihdamı (işgücü)- politik kutuplaşma ilişkisi

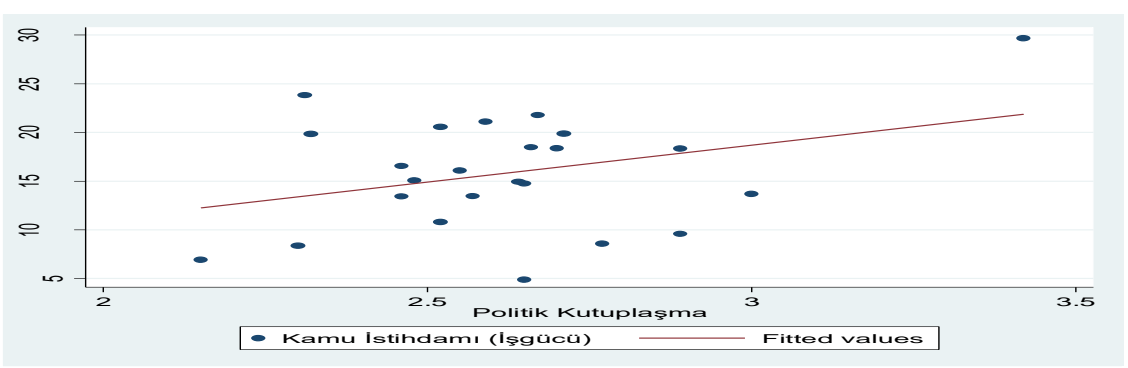

En küçük kareler (EKK) yöntemi ile elde edilen tahmin sonuçları Tablo 3 ’te sunulmuştur.

Tablo 3. Analiz sonucu

\begin{tabular}{|c|c|c|}
\hline Bağımlı Değişken: & Ln (Kamu İstihdamı/nüfus) & Ln (Kamu istihdamı/işgücü) \\
\hline Bağımsız Değişskenler & $\begin{array}{c}\text { Model I } \\
\text { EKK(1) } \\
\text { (t-stat.) }\end{array}$ & $\begin{array}{c}\text { Model II } \\
\text { EKK(2) } \\
\text { (t-stat.) }\end{array}$ \\
\hline Politik Kutuplaşma & $\begin{array}{c}0.396 * * * \\
(2.99)\end{array}$ & $\begin{array}{c}0.320^{* *} \\
(2.96)\end{array}$ \\
\hline Dinsel Çeşitlilik & $\begin{array}{c}0.464 * * * \\
(3.52)\end{array}$ & $\begin{array}{c}0.304 * * \\
(2.35)\end{array}$ \\
\hline Küreselleşme & $\begin{array}{l}-0.004 \\
(-0.65)\end{array}$ & $\begin{array}{l}-0.004 \\
(-0.77)\end{array}$ \\
\hline LnGSYİH & $\begin{array}{c}0.454 * * \\
(2.51)\end{array}$ & $\begin{array}{c}0.394 * * \\
(2.77)\end{array}$ \\
\hline Nüfus Yoğunluğu & $\begin{array}{c}-0.002 * * * \\
(-5.17)\end{array}$ & $\begin{array}{c}-0.001 * * * \\
(-4.45)\end{array}$ \\
\hline İşsizlik Oranı & $\begin{array}{c}-0.015^{*} \\
(-1.85)\end{array}$ & $\begin{array}{c}-0.019 * * \\
(-2.74)\end{array}$ \\
\hline Sabit & $\begin{array}{c}-1.633^{* *} \\
(-2.09)\end{array}$ & $\begin{array}{l}-0.736 \\
(-1.19)\end{array}$ \\
\hline Gözlem & 22 & 22 \\
\hline R-Kare & 0.70 & 0.67 \\
\hline$F$ istatistiği & $12.84 * * *$ & $7.87^{* * * *}$ \\
\hline White Testi & $\begin{array}{c}22.00 \\
(0.399)\end{array}$ & $\begin{array}{c}22.00 \\
(0.399)\end{array}$ \\
\hline Reset Testi & $\begin{array}{c}0.37 \\
(0.773)\end{array}$ & $\begin{array}{c}0.42 \\
(0.741)\end{array}$ \\
\hline
\end{tabular}

Not: $(* * *),(* *),(*)$ sırasıyla $\% 1, \% 5$ ve $\% 10$ düzeyinde istatistiksel olarak anlamlıdır.

a: EKK (1)'de bağımlı değișken olarak kamu istihdamı nüfusun yüzdesi olarak kullanılmıștır.

b: EKK (2)'de bağımlı değişken olarak kamu istihdamı işgücünün yüzdesi olarak kullanılmıştır.

c: Her iki modelde de heteroskedasite ve otokorelasyon sorunu nedeniyle Arellano, Froot ve Rogers tahmincisi kullanılmıștır. tistatistikleri katsayıların altında parantez içinde verilmiştir. 
Model I'de bağımlı değişken kamu istihdamının nüfus içindeki yüzdeki, Model II'de ise kamu istihdamının işgücü içindeki yüzdesidir. İki regresyonda da bağımlı değişkenin doğal logaritması alınmıştır. İki modelde de regresyon spesifikasyon testi (RESET) sonucuna göre bir sepsifikasyon hatası yoktur. Bu durumda iki model de kamu istihdamının modellenmesinde kullanılabilir durumdadır. Ayrıca ilgili literatürde çeşitli yazarlar daha önce açıklandığı gibi regresyonlarda kullanılan bağımlı değişken ile bağımsız değişkenler arasındaki nedensellik linklerinin varlığına ilişkin açıklamalarda bulunmuşlardır.

Elde edilen ampirik sonuçlar her iki modelde de, politik kutuplaşma ile kamu sektörü istihdamı arasında pozitif yönlü ve istatistiksel olarak anlamlı bir ilişkinin olduğunu göstermektedir. Politik kutuplaşma endeksindeki bir birimlik bir artış, kamu istihdam oranın ilgili katsayının değeri kadar bir yüzdeyle arttırmaktadır. Bunu daha ayrıntılı göstermek için

$\operatorname{Ln}(\mathrm{y})=\alpha+\beta X$ şeklinde bir tahmin denklemi varsayalım. Denklemin toplam türevselini aldığımızda (totally differentiating), aşağıdaki denkleme ulaşılır.

$$
\mathrm{dy} / \mathrm{y}=\beta \mathrm{dX}
$$

Buradan dy $=\mathrm{y} \beta \mathrm{dX}$ elde edilir. Diğer bir deyişle bir birimlik X değişimi bağımlı değişkeni y $\beta$ kadar değiştirecektir. Bu da y deki yüzde değişme demek olan dy/y oranının beta kadar olacağını gösterir. Bu açıklama bize yukarıdaki regresyon sonucuna göre, politik kutuplaşma endeksinde bir birimlik bir değişme olduğu zaman kamu istihdam oranında birinci modelde yüzde otuz dokuz ikinci modelde de yüzde otuz iki bir artış olacaktır. Eğer örneğin kamu istihdam oranı yüzde yedi civarında ise, politik kutuplaşmada bir birimlik bir artış, 7X0.39=2.73, yüzde 2.73 kamu istihdamının artmasına yol açacaktır ve kamu istihdam oranı yüzde 9.73'e çıkacaktır. Diğer bir deyişle bir birimlik politik kutuplaşma endeksi artışının kamu istihdamı üzerindeki etkisi var olan kamu istihdamı düzeyine de bağımlı olmaktadır. Bu sonuç nasıl yorumlanabilir? Ülkelerde politik kutuplaşmalar arttıkça diğer bir deyişle devletten beklenen görevler hakkında insanlar arasında görüş ayrılıkları çok yüksek oldukça, kamu sektörü istihdamı artmaktadır. Farklı gruplar devletin güvenceli istihdamından yararlanmak için lobi faaliyetlerini arttırmış ve beklenen istihdam sonucunu da almış olabilirler.

Dinsel çeşitliliğin de her iki modelde kamu istihdam oranını pozitif ve istatistiksel olarak anlamlı bir şekilde etkilediği görülmektedir. Dinsel çeşitlilik endeksi politik kutuplaşma endeksinden ölçüm değerleri bakımından farklıdır. Dinsel çeşitlilik endeksi sıfır (0) ile bir (1) arasında değişen "sürekli" bir değişkendir. Bu durumda örneğin kamu istihdam oranı (nüfus içindeki) hâlihazırda yüzde 7 civarında ise, 0.10 birimlik bir endeks artışı (dinsel çeşitliliğin artması) nüfus içindeki kamu istihdam oranını 7 X 0.464 (regresyon katsayısı) X $0.10=0.324$ birim arttıracaktır. Bu ise yaklaşık yüzde $(0.324 / 7=0.046) 4.6$ istihdam oranını arttıracak ve yeni istihdam oranı $(7+4.6=11.6)$ yüzde 11.6 olacaktır. $\mathrm{Bu}$ açılamalardan sonra endeks değişkenlerinin katsayılarının nasıl yorumlanacağı daha da netlik kazanmıştır. Dinsel çeşitlilik ile kamu istihdamı arasındaki pozitif yönlü bir ilişki, çeşitli dinsel grupların devletin istihdam olanaklarından yararlanmak için devlet aygıtı üzerinde bir lobi ya da baskı grubu oluşturduklarına ilişskin bir gösterge olabilir. Ya da devlet çeşitli dini gruplar arasındaki olası politik çekişmeleri azaltmak için her grup için bir kamu istihdamı kotası gözetiyor olabilir.

Regresyon sonuçlarına göre her iki modelde işsizlik oranının artması kamu istihdamını azaltıcı bir etki yapmaktadır. Diğer bir deyişle örneklemdeki ülkeler bakımından işsizlik oranı artışı kamu istihdam oranını azaltmaktadır. Kamu sektörü işsizlik oranının artışından dolayı açığa çıkan işsizleri kamuda istihdam eden bir yapı oluşturmamış görünmektedir. Tabloya göre örneğin bir birimlik bir işsizlik oranı artışı ( yüzde birlik bir artış) kamu istihdamını, eğer kamu hali hazırda yüzde 7 ise, 7 X (-0.015) X $1=-0.105$ birim azaltmaktadır. Bu azalış miktarı da ($0.105 / 7=-0.015)$, yüzde 1.5 oranında bir azalışa, diğer bir deyişle istihdam oranının $(7-1.5=5.5)$, yüzde 5.5 değerine düşmesine neden olur. 
Regresyon sonuçlarına göre küreselleşme ile kamu istihdamı arasında anlamlı bir ilişki bulunamamıştır. Küreselleşmenin genellikle kamu istihdamını azaltıcı bir etki yapması beklenirken böyle bir bulgu örneklem ülkeleri ve ilgili yıllar bakımından bulunamamıştır.

Gayrisafi yurtiçi hasıladaki artış iki modelde de kamu istihdamını arttırmıştır. Gelir artışı kamu hizmetlerine olan talebi arttırmış görünmektedir. Bu ampirik bulgu yıllar önce Wagner tarafından da gözlemsel olarak dile getirilmiştir. Gayrisafi yurtiçi hâsıla değişkeninin de doğal logaritması alındığından, katsayı esneklik değeri olarak yorumlanır. Örneğin birinci modele göre, gayrisafi yurtiçi hasılada yüzde yüzlük bir artış kamu istihdam oranını yüzde 45 oranında arttırmaktadır. Örneğin milli gelir 25 binden 50 bine çısa (yüzde yüz artış), eğer halihazırdaki kamu istihdamı yüzde 7 ise $(7 \mathrm{X} 0.45=3.15)$, kamu istihdamı $(7+3.15=10.15)$ yüzde 10.15 değerine çıkacaktır.

Nüfus yoğunluğundaki artış ise kamu istihdam oranını azaltmaktadır. Bu da ölçek ekonomilerine ilişkin iyi bir örnek oluşturur. Tabloya göre, örneğin yüz ölçüme düşen nüfus 1000 kişi artsa, kamu istihdamı, eğer halihazırda yüzde 7 oranındaysa, 7 X (-0.002) X 1000=14 birim azalacaktır. Diğer bir ifadeyle kamu istihdam oranı yüzde $(14 / 7=2)$ iki birim azalarak, 7-2=5, yüzde beş seviyesine inecektir. Nüfus yoğunluğunda 1000 kişilik artış kamu istihdamını yüzde 2 azaltacaktır.

Bütün bu regresyon bulguları ve rakamsal büyüklükleri literatürde dile getirilen sınırlar içindedir. $\mathrm{Bu}$ makalenin temel vurgusu olan politik kutuplaşmanın kamu istihdamı üzerindeki etkisinin rakamsal değeri ise bu konudaki ilk bulguları oluşturmaktadır.

Sonuç olarak 22 ülkenin 2000-2018 verileri ile yapılan bu çalışmada politik kutuplaşmadaki artışın kamu istihdamı üzerinde pozitif bir etkiye yol açtığı bulgusuna ulaşılmıştır.

\section{Sonuç}

Devlet hem mal ve hizmet üretimi yoluyla hem de kamu politikaları yoluyla ekonomik performans1 etkilemektedir. Ancak, devletin ekonomik performansa etkisi toplumsal ve tarihsel koşullara göre zamanla farklı nitelik ve biçimler göstermiştir. Bu değişimlerle beraber ayrı sinıflandırmalara tabi tutulan devlete, harcamacı devlet, düzenleyici devlet, vergi toplayıcı devlet ve işveren devlet gibi roller yüklenmiştir.

Dahası, ekonominin içinde bulunduğu koşullara paralel olarak devletler üstlenmiş olduğu görevler çerçevesinde ekonomik ve sosyal yapıya zaman zaman müdahalelerde bulunmuşlardır. Lakin, devletlerin yapısal özelliklerindeki farklılıklar müdahale şekillerinde ve derecesinde ülkeden ülkeye hatta ülke içinde bölgeler arasında da farklılıklar göstermiştir. Bu durum süreç içinde ekonomik ve sosyal yapı içinde devlet müdahalesinin artmasına yol açmıştır. Bilhassa, ekonomik alanda ortaya çıkan gelişmeler, dünya genelinde Keynesyen politikaların uygulama alanı bulması ve kamu mallarına olan talebin artması gibi sebepler devlet müdahalesinin nedenleri arasinda yer almaktadir.

Ayrıca, refah artışıla birlikte dünya genelinde vatandaşların kamu hizmetleri talebinde artışlar olmuş ve devletler vatandaşların taleplerini karşılayabilmek için hem vergi kapasitelerinin genişlemesine hem de kamu hizmetlerini yerine getirecek personelin çoğalmasına yani toplumsal hizmetler alanındaki istihdamda önemli bir büyüme meydana getirmiştir. Sıralanan tüm bu ve benzer olayların ortaya çıkarmış olduğu devletin işveren rolündeki genişleme ekonomik ve sosyal alanda olumlu ve olumsuz birçok etkiye neden olacağından sosyal bilimlerde bu konunun araştırılması gündeme gelmiştir.

Şüphesiz, bir ülkede ekonomiyi etkileyen önemli bir makroekonomik değişken olan devletin işveren rolünün nasıl belirleneceği ve bu rolü etkileyen faktörlerin neler olduğu sorusu önemli bir araştırma konusudur. Bunun nedeni, söz konusu rolün sadece ekonomik ve demografik faktörler tarafından değil aynı zamanda politik düşüncelerle de şekillenmesinden 
kaynaklanmaktadır. Bir ülkede sosyo-ekonomik kutuplaşmanın seçmenler arasındaki fikir ayrılığını arttırarak politik kutuplaşmaya yol açacağı ve bu durumunda devletlerin istihdam politikaları üzerinde etkili olacağı varsayılmaktadır. Bu anlatılanlardan yola çıkarak, bu çalışmada devletin işveren rolünü etkileyen faktörleri açıklamada politik faktörlerden özellikle politik kutuplaşmanın etkisi araştırılmıştır.

Ampirik analiz sonuçlarına göre, politik kutuplaşma ile kamu istihdamı arasında pozitif bir ilişki olduğu görülmektedir. Yani, politik kutuplaşmanın yüksekliği kamu istihdamını arttıran nedenlerindendir. Kutuplaşmanın yüksek olduğu toplumlarda insanlar daha çok devletçi davrandığından devlet güvencesi altında istihdam edilmek isteyeceklerdir. Dinsel çeşitliliğin yüksek olması devlet güvencesi altında istihdam edilme isteğini arttıracaktır. Böylelikle devletlerin kamu istihdamını hem kamu güvenliğini sağlayarak toplumsal istikrasızlığı azaltmak hem de bölgeler arasında gelir dağılımı dengesizliklerini hafifletmek amaçlarıyla kullandıkları varsayılmaktadır. Yüksek nüfus yoğunluğunun kamu istihdamını azalttı̆̆ 1 ve bu durum ölçek ekonomilerine işaret ettiği görülmektedir. Ayrıca, küreselleşme kamu sektörü istihdamı üzerinde negatif bir etkiye sahiptir ancak istatistiksel olarak anlamlı değildir. İşsizlik oranı ile kamu istihdamı arasındaki ilişkide ise, yüksek işsizlik oranının kamu istihdamını azalttığ görülmektedir. Bu durum ele alınan ülkelerde, hükümet politikalarının sonucunun gönüllü işsizlik yarattığ1 ve bireylerin işgücü dışında kalarak boş zaman için farklı tercihler ortaya koyduğu varsayılmaktadır.

Özetle, devletin işveren rolü üzerinde politik kutuplaşmanın ekonomik ve demografik faktörler kadar önemli olduğu görülmektedir. Toplumlarda yüksek düzeyde kutuplaşma söz konusu olduğunda insanlar daha çok devletçi davranma eğilimde olup devlet güvencesi altında çalışma isteklerinin arttığı ortaya çıkmıştır.

\section{Kaynakça}

Ağır, H. ve Kar, M. (2010). Türkiye'de elektrik tüketimi ve ekonomik gelişmişlik düzeyi ilişkisi: yatay kesit analizi. Sosyoekonomi, Özel s., 150-176.

Akdede, S.H. (2012). Income inequality and political polarization and fracturalization: an empirical investigation of some european countries. Bulletin of Economic Research, 64(1), 2030.

Alesina, A., Baqir, R. ve Easterly, W. (1999). Public goods and ethnic divisions. Quarterly Journal of Economics, 114(4), 1243-1284.

Alesina, A., Danninger, S. ve Rostagno, M. (2001). Redistribution through public employment: the case of Italy. IMF Staff,48 (3), 447-473.

Blais, A. B. ve Dion, S. (1993). Do parties make a difference? Parties and the size of government in liberal democracies. American Journal of Political Science, 37(1), 40-62.

Cusack, T. R. N. ve Martin, R. (1989). Political-economic aspects of public employment. European Journal of Political Research, 17(4), 471-500.

Esteban, J. ve D. Ray (2011). Linking conflict to inequality and polarization. American Economic Review, 101(4), 1345-1374.

Esteban, J.M. ve D. Ray (1994). On the measurement of polarization. Econometrica, 62(4), 819851.

European Values Study Group and World Values Association (2006), European and world values surveys wave 3 1995-1998, version 2014-04-09. http://www.worldvaluessurvey.org/WVSDocumentationWV3.jsp. Erişim Tarihi: 17.02.2020. 
European Values Study Group and World Values Association (2006), European and world values surveys wave 4 1999-2004, version 2014-04-09. http://www.worldvaluessurvey.org/WVSDocumentationWV4.jsp Erişim Tarihi:17.02.2020.

European Values Study Group and World Values Association (2006), European and world values $\begin{array}{lllll}\text { surveys wave 2005-2009, } & 5 & \text { version }\end{array}$ http://www.worldvaluessurvey.org/WVSDocumentationWV5.jsp Erişim Tarihi: 17.02.2020.

European Values Study Group and World Values Association (2006), European and world values surveys wave 6 2010-2014, Version 2014-04-09. http://www.worldvaluessurvey.org/WVSDocumentationWV6.jsp Erişim Tarihi: 17.02.2020.

Fiorina, M. P. ve Abrams, S. J. (2008). Political polarization in the american public. The Annual Review of Political Science, 11, 563-588.

Gersbach, H., Muller, P. ve Tejada, O. (2019). Costs of change and political polarization. European Journal of Political Economy, 60, 1-16.

Gimpelson, V. ve Treisman, D. (2002). Fiscal games and public employment: a theory with evidence from Russia. World Politics, 54(2), 145-183.

Gözgör, G., Bilgin, M.H. ve Zimmermann, K.F. (2019). Public employment decline in developing countries in the 21st century: the role of globalization. Economics Letters, 184, 1-4.

Gregory, R. G. ve Borland J. (1999). Recent development in public sector labor markets. in handbook of labor economics, O. Ashenfelter and D. E. Card. Amsterdam (Ed); New York: Elsevier.

Hammouya, M. (1999). Statistics on public sector employment: methodology, structures and trends. Geneva: International Labor Organization.

Ho, K. W. ve Hoon, H. T. (1998). Productivity growth and public sector employment. The American Economist, 42(2), 73-79.

Huber, E. ve Stephens, J. D. (2000). Partisan governance, women's employment, and the social democratic service state. American Sociological Review, 65 (3), 323-342.

ILO, 2000: Current international recommendations on labour statistics. ILO, Geneva.

ILO/EASMAT, 1997: Labour statistics based on administrative records: guidelines on compilation and presentation. ILO Regional Office for Asia and the Pacific, Bangkok.

Katsimi, M. (1998). Explaining the size of the public sector. Public Choice, 96 (1/2), 117-144.

Lindqvist, E. ve Östling, R. (2010). Political polarization and the size of government. The American Political Science Review, 104(3), 543-565.

Mattos, E. ve França, V. (2011). Public employment and income redistribution: causal evidence for Brazilian Municipalities. Public Choice, 146(1/2), 43-73.

Murell, P. (1985). The size of public employment: an empirical study. Journal of Comparative Economics, 9(4), 424-437.

Navruz, B. A. (2007). Türkiye'de kamu istihdamı ve istihdam alaninda kamusal rantlar (Yayımlanmamış yüksek lisans tezi). Anadolu Üniversitesi, Eskişehir.

Rama, M. (1997). Efficient public sector downsizing. Policy Research Working, 1840.

Rodrik, D. (1997). What drives public employment? National Bureau of Economic Research Working 6141. Cambridge, MA: National Bureau of Economic Research.

Rodrik, D. (1998). Why do more open economies have bigger government?. Journal of Political Economy, 106 (5), 997-1032. 
Schiavo-Campo, S. Giulio de T. ve Amitabha M. (1997). An international statistical survey of government employment and wages, Policy Research Working Paper 1806, Washington D.C.: World Bank Institution.

Sevillano, J. M. M. ve Villalonga, J. R. (2004). Public employment and regional redistribution in Spain. Hacienda Pública Española / Revista de Economía Pública, 170 (3), 59-80.

Studenmund, A.H. (1992). Using econometrics: a practical guide, Second Edition, New York:Harper Collins Publishers.

Tait, A. A. ve Heller, P. S. (1984). Government employment and pay: Some International Comparisons, International Monetary Fund, 6365.

Tatoğlu, Y.F. (2013). Panel veri ekonometrisi: stata uygulamalı. (İkinci Bask1), İstanbul: Beta Yayınları.

Vazquez, J.M. ve Yao, M.H. (2009). Fiscal decentralization and public decentralization and public sector employment: a cross-country analysis, Public Finance Review, 37(5), 539-571.

Wallace, T.D. ve Silver, J.L. (1988). Econometrics: an introduction. Reading, Massachusetts:Addison-Wesley Publishing Company.

Wooldridge, Jeffrey M. (2001). Econometric analysis of cross section and panal data. The MIT Press, Cambridge, London.

World Bank (2018). World development indicators 2018, Washington, DC: World Bank.

\section{ETIKK ve BİLIMMSEL İLKELER SORUMLULUK BEYANI}

$\mathrm{Bu}$ çalışmanın tüm hazırlanma süreçlerinde etik kurallara ve bilimsel atıf gösterme ilkelerine riayet edildiğini yazar(lar) beyan eder. Aksi bir durumun tespiti halinde Afyon Kocatepe Üniversitesi Sosyal Bilimler Dergisi'nin hiçbir sorumluluğu olmayıp, tüm sorumluluk makale yazarlarına aittir.

\section{ARAŞTIRMACILARIN MAKALEYE KATKI ORANI BEYANI}

1. yazar katk1 oranı : $\% 50$

2. yazar katk1 oran1 : $\% 50$ 